Summer 2003

\title{
Reconciling Human Rights and Sovereignty: A Framework for Global Property Law
}

Christopher Saporita

Indiana University School of Law

Follow this and additional works at: https://www.repository.law.indiana.edu/ijgls

Part of the Human Rights Law Commons, International Law Commons, and the Property Law and Real Estate Commons

\section{Recommended Citation}

Saporita, Christopher (2003) "Reconciling Human Rights and Sovereignty: A Framework for Global Property Law," Indiana Journal of Global Legal Studies: Vol. 10 : Iss. 2 , Article 9.

Available at: https://www.repository.law.indiana.edu/ijgls/vol10/iss2/9

This Note is brought to you for free and open access by the Law School Journals at Digital Repository @ Maurer Law. It has been accepted for inclusion in Indiana Journal of Global Legal Studies by an authorized editor of Digital Repository@Maurer Law. For more information, please contactrvaughan@indiana.edu.

\section{$\Psi$}

JEROME HALL LAW LIBRARY

INDIANA UNIVERSITY

Maurer School of Law
Bloomington 


\title{
Reconciling Human Rights and Sovereignty: A Framework for Global Property Law
}

\author{
Christopher Saporita*
}

\section{INTRODUCTION}

In the wake of the massive destruction and notorious human rights abuses of World War II, the nations of the world made a widely supported commitment to protecting human rights. Fundamental to this agreement was the understanding that nation-states, previously viewed as impervious to compulsion by extra-national standards of conduct, could not be trusted to protect the rights of individuals. Also fundamental was the agreement that human rights belong to all human beings, regardless of race, color, sex, language, religion, political or other opinion, national or social origin, property, birth, or other status.

In the past fifty years, progress has been made in varying degrees in establishing consensus on particular issues, monitoring human rights abuses, enforcing human rights, and developing a body of law to guide this task into the future. While the nations of the world have agreed on some important fundamental human rights, disagreement persists as to the full set of human needs and activities that should be protected as rights. One view holds that civil and political rights, typically understood as negative rights reserved by the individual against state interference, are the primary bulwark against oppression, and that these rights are sufficient for full realization of equality and prosperity. A contrasting view holds that the state's primary duty is to provide affirmatively for the collective welfare of its citizens. On this view, positive social, economic, and cultural rights are to be promoted before negative civil and political rights.

Parallel to the enhancement of human rights has been the diminution of states' rights, or sovereignty. From the Peace at Westphalia forward, a sovereign's control of its territory and its final authority to make law within its borders have been seen as the fundamental building blocks of international law. ${ }^{1}$

* J.D., 2003, Indiana University School of Law-Bloomington; B.A. 1991, State University of New York at Stony Brook. I would like to recognize and appreciate the invaluable assistance, guidance, and inspiration provided by Professors Susan Williams and Jost Delbrück. I would also like to thank my parents, Margaret and Ronald Saporita, for their faith, coaching, and undying support.

1. See Barry E. Carter \& Phillip R. Trimble, International Law 462-63 (3d ed. 1999). 
Recently, however, global forces, including markets, communications, and transportation, have, become more independent of the control of sovereign states, and a growing number of multilateral agreements with provisions for extra-national enforcement has, to some extent, deprived states of the "last word" on a number of issues previously within their domain. ${ }^{2}$ While most nations desire the benefits of increasingly integrated "globalized" forces, there remains serious disagreement regarding the role of sovereign nations in a global order. One view, espoused by some "globalists," holds that sovereigns are becoming less relevant and less necessary to the extent that wealth (and thus welfare) is created and distributed by global forces. ${ }^{3}$ Some globalists go so far as to argue that sovereignty impedes the true potential of globalization. ${ }^{4}$ Some skeptics, however, argue that globalization is merely a cover for imperialism, ${ }^{5}$ and that sovereigns are still necessary-perhaps increasingly so-to protect the welfare of their citizens, and represent their needs against those of disembodied and unaccountable "global" forces. ${ }^{6}$ It seems that although sovereign nations retain great practical and ideological import, when the interests of global forces and sovereigns come into conflict, the latter are increasingly made to yield. ${ }^{7}$

A third trend brought to center stage by globalization involves the stature and extent of property rights in the global era. Traditionally seen as the exclusive domain of the sovereign, in which states exercise territorial and legislative autonomy, property disputes have become globalized, and the locus of control, at least in certain areas, has steadily shifted from national to transnational arenas. The unsettled nature of property rights is central to understanding this trend, as well as the seemingly intractable disputes regarding the scope of human rights law and the power of the state. The inability to reconcile these disputes stems, at least in part, from a fundamental disagreement about the meaning of property, as well as who should have the final authority to decide how property is protected and ultimately distributed. Mirroring the divergence in human rights and

2. David Held \& Anthony McGrew, The Great Globalization Debate: An Introduction, in ThE Global Transformations Reader: An Introduction to the Globalization Debate 1, 13 (David Held \& Anthony McGrew eds., 2000) [hereinafter The Global Transformations Reader].

3. Id.

4. Jost Delbrück, Globalization of Law, Politics, and Markets-Implications for Domestic LawA European Perspective, i Ind. J. Global Legal Stud. 9, I 4 (1993).

5. Id. at 5 .

6. Id. at 31 .

7. Held \& McGrew, supra note 2, at 13. 
sovereignty, the global dispute over property comes down to the dispute between the liberal ideology that animates free-market capitalism and the socialist ideology that animates state-planned economies. The former view holds that in order to generate industry and wealth, property must be strictly protected against intrusion by the state and others. The latter view holds that in order to ensure that property is equitably distributed, states must retain unencumbered authority to tailor the levels of protection that property receives. Though there is considerable disagreement in this area, there is a general trend toward increasing the protection of private property as against the state and prioritizing speculative property over other types. ${ }^{8}$

This trend in property, more than any other, is at the root of the prioritization of individual rights over collective welfare, and the ascendance of global market forces over sovereign authority. The results are the decreased stature of and commitment to social, economic, and cultural rights, the diminished capacity of states to protect public welfare within their territories, and a distortion of civil and political rights.

If we hope to reconcile the divergence in these crucial areas, the global community must articulate an answer to this fundamental question: How should we treat property in a global world? In order to do so, we must decide the following: what is the purpose of property, why or when does it deserve legal protection, and how can we enforce those protections? Though these questions are enormous, this note will provide a modest contribution to this dialogue, in the hope that we will begin to come to terms with the importance of property in defining — and defending — human rights in a globalized world.

Part I of this note will explore the effects of parallel global trends in human rights, sovereignty, and property towards individualism, globalization, and

8. See Eduardo Moisés Peñalver, Redistributing Property: Natural Law, International Norms, and the Property Reforms of the Cuban Revolution, 52 FLA. L. REv. 107,109 (2000) (noting the growing consensus around liberal markets and property rights); see also Martin Shapiro, The Globalization of Law, 1 Ind. J. Global LeGal Stud. 37, 39 (arguing that globalization "through private corporate lawmaking rather naturally takes the form of the global Americanization of commercial law"); 2 Encyclopedia of Public International Law 323 (1992) ("It is not surprising to ascertain that recent international state practice on matters of expropriation to a remarkable degree coincides with modern rules of national law in liberal states."); see generally J. Martin Wagner, International Investment, Expropriation, and Environmental Protection, 29 Golden Gate U. L. Rev. 465, 502 (1999) (describing attempts by the U.S. government and multinational investors to use the growing number of international investment treaties to promote adoption of property protections that are even stronger than those provided by U.S. law). 
liberalism, respectively. Part II will then address some of the impacts that these trends are having on social, economic, and cultural rights; on public welfare protection; and on civil and political rights. Part III will compare and contrast three alternative theories of property that seek to elevate human needs above speculative interests. Part IV will attempt to articulate a vision of property that reconciles civil/political rights with social/economic/cultural rights in the context of a continuing role for sovereign states.

\section{Global Trends}

\section{A. Human Rights}

Since the end of World War II, the international community has reached fundamental agreement on human rights in international law. ${ }^{9}$ At the foundation of this agreement is the belief that states have an obligation to respect and protect the rights of their citizens, and that these rights can be enforced by other states. ${ }^{10}$ While relatively new, this international consensus has advanced rapidly, resulting in a host of treaties, resolutions, conventions, and declarations covering almost every area of human life. ${ }^{11}$ The strongest agreements are those relating to the basic right to life and freedom, manifesting themselves in international prohibitions on torture, slavery, and genocide. ${ }^{12}$ While contrary state practices ${ }^{13}$ (slavery and widespread use of torture) demonstrate that these agreements are often little more than rhetoric, nearly all states publicly agree with these fundamental rights.

9. 2 Encyclopedia of Public International Law 886 (1992) (“In national constitutions, and by international instruments of varying political and legal significance, virtually all States have embraced the idea of human rights, and have indicated general agreement as to their content.") [hereinafter 2 Encyclopedia of Public International Law].

10. Richard B. Bilder, An Overview of International Human Rights Law, in Guide to International Human Rights Practice 3 (Hurst Hannum ed., 1984).

11. See, e.g., International Covenant on Civil and Political Rights, Dec. 16, 1966, 999 U.N.T.S. 171 [hereinafter ICCPR]; International Covenant on Economic, Social, and Cultural Rights, Dec. 16, 1966, 993 U.N.T.S. 3 [hereinafter ICESCR]; Universal Declaration of Human Rights, G.A. Res. 217A(III), U.N. Doc. A/810 (1948) [hereinafter UDHR].

12. See Convention Against Torture and Other Cruel, Inhuman, or Degrading Treatment or Punishment, Dec. 10, 1984, 23 I.L.M. 1027 (1984), as modified, 24 I.L.M. 535 (1985); Convention on the Prevention and Punishment of the Crime of Genocide, Dec. 9, 1948, 78 U.N.T.S. 277.

13. Peñalver, supra note 8 , at 137. 
Despite these fundamental agreements regarding basic human rights, there remains significant discord about what other needs and interests should be enshrined as human rights and protected by international law. Economic, political, and ideological tensions have thwarted attempts to reconcile the fundamental differences between two of the major agreements on human rights: the International Convention on Civil and Political Rights (ICCPR) ${ }^{14}$ and the International Convention on Economic, Social, and Cultural Rights (ICESCR). ${ }^{15}$ The bifurcated nature of these conventions, signed at the height of the Cold War (1966), reflects a deep divide between "positive" rights, favoring greater responsibility and a more active role for government in promoting economic, social, and cultural rights to food, housing, health care, education, and employment, and negative rights, centered on limiting the role of government and protecting civil and political rights by preventing government from abridging life, liberty, and democracy. ${ }^{16}$

Both conventions begin with a commitment to self-determination, nondiscrimination, and gender equality. ${ }^{17}$ Beyond that, the ideological differences become apparent. The ICCPR (ratified by 147 countries, including the United States and the Soviet Union) focuses on liberty interests, and limits government responsibility to providing due process when liberty and security are abridged by state action. By contrast, the ICESCR (ratified by 143 countries, including the Soviet Union, but not the United States) focuses on human needs beyond liberal rights, and affirms the state's responsibility to undertake efforts to provide for these needs. During the drafting process, some governments of socialist states asserted a broad power to limit rights where necessary to meet the needs of socialism; conversely, some liberal states asserted that the right to work ${ }^{18}$ only requires equal access to work and freedom to choose one's work, and does not create an affirmative duty by the state to provide work. ${ }^{19}$ These positions reflect the different ideologies underpinning the power of the state to circumscribe civil/political rights, and the responsibility of the state to provide social/economic/cultural rights.

14. ICCPR, supra note 11.

15. ICESCR, supra note 11.

16. Asbjørn Eide \& Allan Rosas, Economic, Social and Cultural Rights: $A$ Universal Challenge, in Economic, Social and Cultural Rights: A Textbook 15, 17 (Asbjørn Eide et al. eds., 1995) [hereinafter Economic, Social and Cultural Rights].

17. ICCPR, supra note 11, arts. I-3; ICESCR, supra note 10, arts. I-3.

18. ICESCR, supra note 11 , art. 6.

19. 2 Encyclopedia of Public International Law, supra note 8 , at 890. 
Though this ideological divide is not evident on the face of the conventions, it can be seen in the language of each agreement's Article 4, both of which describe a state's right to derogate from the provisions contained in each convention. ${ }^{20}$ Both conventions' Article 4 circumscribe these powers of derogation. In the ICCPR, Article 4 provides that a state may derogate from its responsibilities under the convention only "[i]n time of public emergency which threatens the life of the nation and the existence of which is officially proclaimed."21 In the ICESCR, the state may limit the rights in the convention "solely for the purpose of promoting the general welfare." 22 Thus, not only has the United States-the strongest proponent of civil/political rights-denied an obligation to provide social/economic/cultural rights, but the language of these treaties also permits states easily to avoid their obligation to provide social/economic/cultural rights, by creating a hierarchy of rights that strongly protects civil/political rights. In addition to the different legal priorities given to the two sets of rights, there are practical factors that cause social/economic/cultural rights to be inadequately enforced. Because these rights often take the form of a right to something, a state's willingness and ability to provide for these rights will require greater political or legislative will, and more substantial financial commitments. ${ }^{23}$ By contrast, civil/political rights often require the state only to abstain from doing something. ${ }^{24}$

The ultimate implication of this hierarchy of rights is not just that civil/ political rights matter more than social/economic/cultural rights, but that when the two come into conflict, the former will prevail. This weaker status of the rights described in the ICESCR has led several authors to conclude that human rights law is incomplete because it neglects issues of economic rights. As one author put it, "human rights related to economic justice have been labeled the 'stepchild' of the human rights movement."25

20. ICCPR, supra note 11 , art. 4 ; ICESCR, supra note 11 , art. 4.

21. ICCPR, supra note 11 , art 4.1 .

22. ICESCR, supra note 11 , art 4.

23. Asbjørn Eide, Economic, Social and Cultural Rights as Human Rights, in Economic, Cultural and Social Rights, supra note 16, at 21, 22-23.

24. Id.

25. Peñalver, supra note 8 , at 139. 


\section{B. Sovereignty}

In the years since the Peace of Westphalia, sovereignty has been recognized as the sine qua non of international law, allowing international law to govern the relationships between sovereign states. ${ }^{26}$ Article I of the Montevideo Convention of 1933 provided: "The state as a person of international law should possess the following qualifications: (a) a permanent population; (b) a defined territory; (c) government; and (d) capacity to enter into relations with other states." ${ }^{27}$ These basic elements of a state are echoed and described further in the Restatement (Third) of Foreign Relations Law of the United States, § 201. Among the powers enjoyed by states are sovereignty, status as a legal person, and the capacity to join other states in making international law. ${ }^{28}$

It is also widely held that all states are equal under law and entitled to selfdetermination, and, concomitantly, that other states may not intervene in the internal affairs of each other. ${ }^{29}$ "Traditional understandings of sovereignty have ascribed to that concept the characteristics of unlimited freedom and absolute authority for each state within its own territories. ${ }^{30}$ To that end, all states may exercise general police powers and the power of eminent domain. These powers permit states to pass civil and criminal laws, govern the conduct of their citizens, determine the allocation of their resources, and define their form of government. These broad powers are predicated on the state's role as guardian and representative of its nationals' welfare.

The meaning and extent of sovereignty has long been an issue of contention in international law, and in the era of globalization, the debate has taken on new dimensions and urgency. This modern debate has been framed as a debate between globalists, who argue that sovereignty has become less relevant in the face of globalizing forces, ${ }^{31}$ and skeptics, who argue that "globalization" is merely an

26. See Anne C. Dowling, "Un-Locke-ing" a "Just Right" Environmental Regime: Overcoming the Three Bears of International Environmentalism-Sovereignty, Locke, and Compensation, 26 WM. \& Mary Envtl. L. \& Pol'y Rev. 891, 894 (2002).

27. Montevideo Convention on the Rights and Duties of States, Dec. 26, 1933, art. I, quoted in CARTER \& TRIMbLe, supra note 1 , at 462.

28. Restatement (Third) of Foreign Relations Law of the United States $§ 206$ [hereinafter Restatement].

29. 4 Encyclopedia of Public International Law, supra note 9, at 512.

30. Dowling, supra note 26.

31. Held \& McGrew, supra note 2, at 13. 
ideological front for the "pathological expansionist logic" of capitalism, ${ }^{32}$ which has no concrete reality. ${ }^{33}$ Skeptics argue that sovereignty is, and must remain, absolute. ${ }^{34}$ This position reflects a deeply local emphasis on the state as the guardian of its citizens' welfare, and as a combatant in international relations. Under this model, a state must have the final word on all issues regarding its nationals and its territories in order to maintain public order and the authority to negotiate from a position of egoistic self-interest. ${ }^{35}$ Without this authority, the peoples of smaller, less powerful states will be without adequate protection and representation.

Globalists, on the other hand, describe a world increasingly subject to denationalization of political, economic, and social activities, ${ }^{36}$ where "the power and role of the territorial nation-state is in decline." ${ }^{37}$ For example, today's financial markets are said to be globalized because the movement of capital has largely become independent of the sovereign control of state agencies, due, in part, to the telecommunications revolution. ${ }^{38}$ As a result, states suffer a "diminution in power because the expansion of transnational forces reduces the control individual governments can exercise over the activities of their citizens and other peoples." 39 Many of the areas in which the state has traditionally maintained responsibility and authority (defense, economic management, health, and law and order) now require transnational collaboration." ${ }^{40} \mathrm{Also}$, as the binding nature of directives in the European Community demonstrates, "domestic law is set aside" 41 by supranational law that is "independent of the sovereign will of the Member States and is backed up by the enforcement powers of the ECJ."42 Under the globalist model, states are becoming less and less capable of making unilateral legal and territorial decisions. ${ }^{43}$

32. Id. at 5 .

33. Id. at 2 .

34. Dowling, supra note 26 , at 898 .

35. Id. at 898-99.

36. Delbrück, supra note 4 , at i 1 .

37. Held \& McGrew, supra note 2, at 13.

38. Delbrück, supra note 4 , at 10.

39. Held \& McGrew, supra note 2, at 13.

40. Id.

41. Delbrück, supra note 4 , at 34 .

42. Id.

43. Held \& McGrew, supra note 2, at 11. 


\section{Property Rights}

The divergence in global discourse about human rights and the divergence about states' rights share a common root. As we have seen, these disagreements have been framed in terms of liberal/socialist and globalist/statist dichotomies, respectively, and have both been understood as representing the tension between (theoretically) absolute individual autonomy and (theoretically) absolute state power. But these dichotomies center around one of the most profound, yet incomplete, legal concepts: property. For it is property law that defines the limits of what the state may control, ${ }^{44}$ and what an individual may control, and thus what the respective role of each is in attaining a just distribution of wealth and welfare.

Both liberalism and socialism agree with the fundamental legal outlines of a state's control of property. As noted previously, sovereignty includes a state's control over its territory, as well as general authority over its nationals. ${ }^{45}$ Because states are defined by their control over territory, ${ }^{46}$ it is a central tenet of international law that such control is complete, and this necessarily includes all property: real, personal, tangible, and intangible. Thus, international law recognizes that all states may exercise general police powers, as well as the power of eminent domain. Both powers are predicated on the state's role as guardian and representative of its nationals' welfare. The police power permits states to pass civil and criminal laws to govern the conduct of its citizens, and to define its form of government. The power of eminent domain refers to the state's ultimate authority to acquire use and/or possession of property within its territory for the public good. ${ }^{47}$ In both liberal and socialist traditions, the state retains broad power to abrogate property rights for the promotion of public purposes. ${ }^{48}$

44. Charles A. Reich, The New Property, 73 Yale L.J. 733 (1964) (noting that "[p]roperty guards the troubled boundary between individual man and the state").

45. Restatement, supra note $28, \S 206($ a).

46. Trimble \& Carter, supra note 1 , at 462.

47. See G.A. Res. 1803(XVII), U.N. GAOR Secretariat Centre for Human Rights $\$ 4$ (1962), available at http://193.194.138.190/html/menu3/b/c_natres.htm [hereinafter Res. 1803]; see also Jon A. Stanley, Keeping Big Brother Out of Our Backyard: Regulatory Takings as Defined in International Law and Compared to American Fifth Amendment Jurisprudence, 15 Emory Int'l L. Rev. 349, 372 (2001).

48. Res. 1803, supra note 47, $\$ 4$; see also Restatement, supra note 28 , $\$ 443$; Hawaii Hous. Auth. v. Midkiff, 467 U.S. 229 (1984) (upholding a state law that gives the state the authority to take the fee simple title to realty from owner-lessors and transfer it to lessees in order to reduce the concentration of fee simple ownership). 
But defining the contours of the property rights retained by an individual, as against the state, is difficult, especially in a globalized economy. In modern liberal thought, property is a monolithic type, and an end in and of itself. ${ }^{49}$ It is a "natural right," of equal importance to other fundamental civil rights and deserving of an equivalent level of protection. ${ }^{50}$ In order to protect the individual from government oppression, property must be protected from invasion, and imbued with legal stability and strong expectations of security. In socialist thought, property is a means to an end, subsumed by the purposes of shoring up social/economic/cultural rights. In order to protect the people from inequitable distribution of wealth and alienation of labor, property must be easily subject to control by the state, and not allowed to accrue in one class (capitalists) to the detriment of others (workers). ${ }^{51}$

The importance of this divergence in property theories can be understood by examining the law of expropriation. Expropriation occurs when a state takes possession of formerly private property for public purposes. The unsettled nature of the law in this area highlights the depth of division and lack of clarity regarding the role of property rights in international law. While the power of eminent domain is effectively absolute, it receives legitimacy from the implicit understanding that the people subject themselves to it (as they subject themselves to the sovereign) for the greater public good. Thus a state may expropriate private property only when it is necessary, and in a good faith effort to promote the general welfare. ${ }^{52}$ Even with that limitation, international courts and tribunals have consistently upheld a state's broad discretion in defining the extent of their eminent domain powers. ${ }^{53}$ Several decisions have required a balancing of the public interest and the private property right, but this balancing invariably comes out in favor of permitting the government to exercise its broad police powers. ${ }^{54}$

Beyond this functional agreement regarding the appropriateness of, or deference to, expropriation, three important issues remain unresolved. The first relates to the extent of a state's obligation to compensate nationals and aliens for

49. Peñalver, supra note 8 , at 188 .

50. Id.

51. See Karl Marx \& Friedrich Engels, Proletarians and Comminists, from the Communist Manifesto, in Liberty, Property, and the Law: Classical Foundations of Liberty and Property 2 ig (Richard A. Epstein ed., 2000).

52. See Roger A. Cunningham et al., The Law of Property 509 (2d ed. 1993).

53. Stanley, supra note 47 , at 372,374 .

54. Id. at 372 . 
the direct deprivation of property (expropriation). ${ }^{55}$ The second relates to the determination of when a state's exercise of its regulatory power creates such a significant deprivation of property as to amount to expropriation, and thus require compensation. ${ }^{56}$ The third, and perhaps most important issue, is defining property for purposes of protection by international law. ${ }^{57}$ The ultimate answers to these questions will have an enormous impact on the achievement of social/economic/cultural rights, and the future of sovereignty, because they go to the very heart of government's ability to structure the material relationships upon which all people depend.

There is no consensus on how much compensation is due to a property holder whose property is expropriated, but three rules are vying for dominance. ${ }^{58}$ The first is the "national treatment" standard, which holds that international law requires only that an expropriating country compensate aliens to the same extent that it compensates nationals. ${ }^{59}$ The national treatment standard has been overwhelmingly endorsed by U.N. Resolutions. For example, the standard was endorsed in the Charter of Economic Rights and Duties of States (CERDS) by a vote of 120-6-10, with the abstentions and no votes coming from industrialized countries (including the United States and Western Europe). ${ }^{60}$ The second standard, long followed and still endorsed by the United States and other capital-exporting countries, is the "prompt, adequate, and effective" standard. ${ }^{61}$ This rule emerged from the practice of colonial empires, and essentially requires states to pay the market value of the expropriated property. ${ }^{62}$ The third rule is the "partial compensation" standard. This standard holds that certain types of expropriations (such as taking land for a highway) require compensation, while others (such as systematic land reform) do not, and that, in the latter cases, states may provide less than full (market value) compensation. ${ }^{63}$

55. 2 Encyclopedia of Public International Law, supra note 9, at 321.

56. Id.

57. Id.

58. See Peñalver, supra note 8 , at $140-48$.

59. Id. at $143-47$.

60. Id. at 146 .

61. Id. at $140-43$.

62. This is similar to the standard adopted by the U.S. Supreme Court in Shoemaker $v$. United States, 147 U.S. 282, 285 (1893) (holding that for purposes of the Fifth Amendment of the U.S. Constitution, "just compensation" means market value).

63. See Peñalver, supra note 8 , at 147-48. 
The question of when a government action or regulation that diminishes the value of private property requires compensation is increasingly important. This is an area where a radically conservative idea, influential in the United States, is having an impact on international law. In U.S. Supreme Court jurisprudence, the idea is referred to as a "regulatory taking." ${ }^{64}$ In international law, the same idea, as it applies to the property of foreign nationals, is called "indirect expropriation." 65 Because the United States is one of the leading capitalexporting states, U.S. law has had a strong influence on the development of international law regarding investment, trade, and indirect expropriation. ${ }^{66}$ This question essentially broadens the inquiry into when a taking has occurred by expanding the number of state actions that may trigger a right to compensation. While indirect expropriation exists in theory, the vast majority of such claims by alien claimants are denied $:{ }^{67}$ the government must physically take possession of property in order for a taking to be compensable. This follows logically from the great deference that international tribunals have afforded to states in applying their police powers. ${ }^{6}$

However, in the United States regulatory takings constitute a real cause of action, and a recent decision by the Supreme Court has arguably expanded the scope of such claims. In Lucas v. South Carolina Coastal Council, ${ }^{69}$ the Court held that a taking occurs when a regulation deprives the property holder of any "economically beneficial uses" of his property, unless the regulation prohibits a use that is already impermissible under nuisance law. ${ }^{70}$

Emboldened by emerging U.S. property rights theory, and frustrated by the unresponsiveness of international law to ensure compensation, state parties to trade agreements have included provisions that model, and even exceed, the protection of U.S. Supreme Court takings jurisprudence by giving companies an

64. See Wagner, supra note 8 , at 502-09.

65. See id. at 466.

66. See Shapiro, supra note 8, at 39; see also Wagner, supra note 8, at 501 (describing the strong influence of the United States on indirect expropriation).

67. See Stanley, supra note 47, at 372 .

68. See id.

69. 505 U.S. 1003 (1992).

70. Id. at 1023, 1027. But see generally James M. McElfish Jr., Property Rights, Property Roots: Rediscovering the Basis for Legal Protection of the Environment, 24 ELR 10231 (1994) (arguing that most regulatory takings claims are attempts to redefine, not preserve, the rights associated with private property). 
enforceable right against participating states to compensation for direct and indirect expropriation. ${ }^{71}$ These provisions are included in numerous bilateral investment treaties (BITs), the North American Free Trade Agreement (NAFTA), and the proposed Multilateral Agreement on Investment (MAI). ${ }^{72}$ Capital-exporting countries herald these agreements as a clear indication of a change of consensus in international law. But this conclusion is not well supported. Consistent, contrary state practice and numerous widely supported U.N. Resolutions to the contrary indicate that the "prompt, adequate, and effective" standard may reasonably be seen as a bargaining concession that capital-importing countries believe is required in order to attract investment. ${ }^{73}$ Whatever the status of "international law" in this area, these provisions establish radically new and dangerous limits on the ability of states to regulate in order to protect public welfare. It is clear that market globalization is promoting, if not founded upon, the idea that private property is more fundamental than the power of the state to arrange the distribution of resources to meet human needs. ${ }^{74}$

\section{Global Problems}

The emerging dominance of liberal/market property theory is problematic for several reasons. First, it views private ownership as an unmitigated good..$^{75}$ This leads adherents to embrace robust property rights without skepticism. ${ }^{76}$ Second, it increasingly rejects limits on property rights derived from social needs, ${ }^{7}$ thereby making it harder for states to change property distributions to adapt to changing circumstances. Third, these theories treat property as its own end, divorced from any animating purpose or value. ${ }^{78}$ In the extreme, this permits a calculus whereby other values, even including human life, can be sacrificed to protect private property rights. Fourth, liberal property theory harbors "excessive faith in market mechanisms as the means of distributing the goods of

\footnotetext{
71. See Wagner, supra note 8, at 472-86.

72. Sec id.

73. See Peñalver, supra note 8, at 152.

74. See id. at 142.

75. See id. at 186-87.

76. See id.

77. See id. at 187.

78. Id. at 188 .
} 
society." ${ }^{" 79}$ As a result, "[d]isembedded global markets make societies conform to the logic of commercialization." ${ }^{80}$ This elevation of rights in speculative property has led to three major crises in human rights, namely, the demotion of social, economic, and cultural rights, the weakening of the state's ability to protect public welfare, and the distortion of civil/political rights.

\section{A. Demotion of Social, Economic, and Cultural Rights}

The bending of property rights to benefit commercial interests overvalues development and speculation at the expense of basic human needs and human rights. Government condemnation of communities, influenced and supported by Western investment, allows developers, road builders, mining companies, and international financiers to take private property for development and displace millions of people each year. ${ }^{81}$ This results in widespread poverty, loss of homes, schools, health care, and livelihoods, as well as social and cultural disorientation, ${ }^{82}$ in direct contravention of the guarantees contained in the ICESR ${ }^{83}$ This situation is exacerbated by the fact that the standard market-value compensation (where it is actually paid) is not sufficient to account and compensate for all of the loss and suffering that displaced people endure. For example, in 1999 , the World Bank approved a $\$ 160$ million loan to China, which China plans to use to displace 58,000 poor farmers from their homes and land, and to relocate them to a sparsely populated part of Tibet in order to exert political control in the region and supply labor for a planned oil pipeline. ${ }^{84}$ As Robert Latham points out, "there is every reason to believe that, in the face of the global forces described above, things will be getting worse." ${ }^{\circ 5}$

79. Id. at 195.

80. Robert Latham, Globalization and the Transformation of Economic Rights, in Globalization and the Politics of Resistance 76, 78 (Barry K. Gills ed., 2000)

81. See International Network on Displacement and Resettlement, at http://www. displacement.net.

82. See Theodore E. Downing, Mitigating Social Impoverishment When People Are Involuntarily Displaced, at http://www.ted-downing.com/papers/didi1.htm [hereinafter Downing]

83. See ICESCR, supra note 11, arts. 6, 10, 11, 15.

84. See Hilary French, Vanishing Borders: Protecting the Planet in the Age of GlobalIZATION I35 (2000).

85. Latham, supra note 80 , at 85. 


\section{B. Demotion of Public Welfare}

Trade agreements that expansively define expropriation-and subject states to direct suit from corporations and individuals - threaten to have a chilling effect on the ability of governments to regulate in the public interest by giving companies the right to base claims for compensation on the economic impact (much of it prospective) of environmental and other public health regulations. ${ }^{86}$ In one example, Ethyl Corporation, a U.S. company with a wholly owned subsidiary in Canada, sued the Canadian government for $\$ 250$ million for indirect expropriation under NAFTA Article 1110. Canada had enacted legislation that made it a crime to import or trade manganese-based substances between provinces due to public health concerns about adverse neurological effects similar to mild Parkinson's disease. ${ }^{87}$ Ethyl Corporation's complaint alleged that the Canadian government could not scientifically support its allegations of risk, and was in fact simply protecting domestic producers of the substances. Due to internal pressure from several provincial governments, Canada settled the case for thirteen million dollars.

\section{Distortion of Civil/Political Rights}

In addition to disadvantaging social/economic/cultural rights and constraining the ability of states to protect the public, the ascendance of liberal property rights also departs from its own philosophical roots to undermine the promise of civil/political rights, including equal opportunity, democracy, and self-determination. Lockean theory posits an important limit to these rights. Locke argued that the right of appropriation of resources from nature existed only so long as there is "enough and as good left in common for others." 88 But global capitalism seems to have forgotten this caveat. For example, the income of the world's richest one percent equals that of the poorest fifty-seven percent, while nearly one-fourth of the world's population lives on less than one dollar per day. ${ }^{89}$ More than 840 million people in the world are malnourished, and six

86. See Wagner, supra note 8 , at 467.

87. See id. at $490-91$.

88. Thomas C. Grey, Property and Need: The Welfare State and Theories of Distributive Justice, 28 Stan. L. Rev. 877, 888 (1976).

89. U.N. Development Programme, Human Development Report 2002: Deepening DemocRACY IN A FraGmented WORLD (2002), available at http:/www.undp.org/hdr2002/. 
million children under the age of five die every year as a result of hunger. ${ }^{90}$ As John Rawls argues, in a world characterized by excessive inequality of wealth, equal opportunity is put at risk "and political liberty likewise tends to lose its value, and representative government to become such in appearance only." 91 And as Thomas C. Grey notes, "a necessitous man is not a free man." ${ }^{92}$ In conditions of poverty and severe need, the poor cannot enter into transactions for housing, employment, and other basic needs freely and voluntarily, ${ }^{93}$ thus undermining the liberal ideals of individual autonomy and dignity. ${ }^{94}$

\section{Property with Purpose}

There is a great irony about property: the increasing financial value of property, as a market concept, is inversely proportional to its normative moral value, as a legal concept. That is to say, as a particular article of property becomes more alienable, it becomes easier to trade, yet loses its particular relationship to human needs and rights. The evidence for this fact comes, in one extreme example, from the international consensus that a person's body is inalienable. ${ }^{95}$ As Locke notes, "every Man has a Property in his own Person." ${ }^{66}$ Thus, if we imagine such property as protecting a person's human needs and rights, including life, bodily integrity, dignity, and autonomy, we can see that allowing human beings to be sold (allowing the property rights to be transferred to another) severs the connection between the object and its human context. ${ }^{97}$

Not so ironic is the observation that as property becomes more aligned with negative rights, it precludes the realization of positive rights. As stated earlier, social, economic, and cultural rights, considered by some to be the "'stepchild' of the human rights movement," 98 are perhaps better understood as the orphan of

90. Food and Agriculture Organization of the United Nations, State of Food Insecurity IN THE WORLD 2002 (2002), available at http://www.fao.org/docrep/005/y7352e/y $7352 \mathrm{e} 00 . \mathrm{htm}$.

91. John Rawls, A Theory of Justice 278 (1971).

92. Grey, supra note 88 , at 893.

93. Id.

94. Id. at 893-94.

95. UDHR, supra note 11, art. 4; ICCPR, supra note 11, art. 8.

96. Margaret Jane Radin, Property and Personhood, 34 Stan. L. Rev. 957, 965 (1982) (quoting John Locke, Second Treatise of Government ch. V, $\$ 27$ (1952) (6th ed. 1764)).

97. Id. at 966.

98. See Peñalver, supra note 8, at 139 (citing Henry J. Steiner ex al., Transnational Legal Problems 337, 361 (4th ed. 1994)). 
the human rights movement. They have been orphaned because property, upon which they rely, has abandoned its social purpose.

Therefore, in order to reconcile civil and political rights with social, economic, and cultural rights, we must reconcile financial value with moral value and negative rights with positive rights. Only then can we create a common space in which these opposing world-views can cooperate, and in which we can realize the best that each has to offer. Only in this way can we bring social, economic, and cultural rights the attention and protection that they require.

To begin, we must articulate our shared values about property rights, and the role that property plays in relation to other human rights. We must, as Robert Latham says, "reinject social purpose into economic life." 99 Many authors have attempted this project. I will describe just three efforts that I believe are most helpful in framing the issues and offering suggestions. I will then offer my own comments on these suggestions, and recommend a framework for implementing value-driven global property rights.

\section{A. Provisionism}

Robert Latham, drawing on the writings of Karl Polanyi, offers an important reminder that I will take as a starting point in exploring the purpose of property. The activity that is basic to all societies is the "provision of the means of existence." 100 Polanyi, writing in 1944, showed how the organization of material life around markets overlooked the possibility that market systems would "form their own logic, laws, and interests separate from the rest of society," detaching from, and ignoring, "the more basic social purpose of supplying all of humankind ... "with the means of material want-satisfaction."'101 Latham goes on to say that "[p]rovisionism begins from the basic proposition that the purpose of institutions and activities that shape material life is to provide communities with goods, services, and other values necessary to sustain community or group life, free of deprivation." 102

99. Latham, supra note 80 , at 84 .

100. Id. at 82 .

101. See id. (citing Karl Polanyi, The Great Transformation: The Political and Economic Origins of OUR Time (1944)).

102. Id. at 83 . 
Latham's view can properly be regarded as globalist, yet he writes from within the movement to resist the dislocation and social insecurity that attend globalization. He is skeptical about the potential for sovereign states to resist the destabilizing effects of "disembedded" markets for several reasons. First, there is an assumption that help for the developing states will come from the wealthier developed nations - a hope that history does not bear out. Second, state and national elites may be unduly influenced by corporations. Finally, it is difficult to see how local forces, with limited authority, can take on detached global market networks. ${ }^{103}$ Ultimately, however, Latham concludes that provisionism must be informed by the local, and can "provide a normative basis to contest and discipline state policies as well as market outcomes." ${ }^{104}$ Latham envisions "new forms of collaborative regulations between states and societies at the global level." 105

\section{B. Personhood Property}

In her landmark article, "Property and Personhood," Margaret Radin discerns in American property law a person-centered value system that she claims consistently affects outcomes in property decisions, yet remains unexplored. ${ }^{106}$ Her "intuitive" view of property is that the amount of protection afforded property in a particular dispute depends (as it should) on the extent to which we constitute ourselves as persons through our possession and/or interaction with an object. ${ }^{107}$ For example, a wedding ring, a portrait, or a house would be considered personal (constitutive) property because the owner is bound up with it in a way that is unique to the person, and the pain of losing the object cannot be relieved by a replacement. ${ }^{108}$ Conversely, property that is not personal is fungible: its loss does not engender pain and it can be replaced.

Though framed as a dichotomy (constitutive versus fungible), Radin conceives of her metaphor as a continuum. ${ }^{109}$ Where property resides along that spectrum determines the level of protection to which it is entitled. Thus, the

\footnotetext{
103. See id. at $80-81$.

104. Id. at 85 .

105. Id. at 86 .

106. Radin, supra note 96.

107. Id. at 960.

108. See id. at 959.

109. Id. at 986 .
} 
more closely an object is connected with personhood, the stronger the entitlement. For example, when a person lives in the house she owns, the house is closer to the personal end of the spectrum than when she owns a house, but rents it to others.

Radin illustrates her theory with a number of examples from positive law. In the first category, she illustrates the importance of home. For example, she attributes the Supreme Courr's decision in Stanley v. Georgia ${ }^{110}$ in which a state law prohibiting the possession of obscenity in the home was ruled unconstitutional, to more than just protection of the right to privacy. Looking at it in terms of personhood considerations, she concludes that the Court was influenced by our society's sense of connection between one's home and one's sense of autonomy and personhood. She also views certain landlord/tenant statures as being influenced by personhood considerations, arguing, "[t]he notion that the law should grant permanent tenure to tenants during good behavior, regardless of what the lease contract says about the term, is a more direct instance of the personhood perspective applied to residential tenancies." 11

Regarding takings, Radin asserts that some personhood property may be so personal that compensation would not be adequate, and thus should not be subject to taking because doing so would cause the person to cease to be "herself." This would amount to a strict scrutiny-type test, whereas the taking of fungible property does not compromise personhood and can be compensated effectively with money.

Radin also creates a separate category of cases that she frames as fungible property interests versus personal non-property interests. ${ }^{112}$ For example, personhood theory might explain why health care workers, union organizers, or protestors should be allowed on (fungible) business property such as a farm, a factory, or a mall, by viewing the dispute as one between the property owner's fungible interest in the property and the non-owner's personhood interest in health care, employment security, or speech. Radin suggests that this analysis would require a balancing test between the two interests. ${ }^{113}$

110. Id. at 991 .

111. Id. at 994 .

112. Id. at 1008 .

113. Id. at 1009 . 


\section{Property for Dignity}

In "Redistributing Property: Natural Law, International Norms, and the Property Reforms of the Cuban Revolution," Eduardo Moisés Peñalver sets out to establish an "ethically-grounded theory of international law and human rights"114 and to link human rights and property law. The central premise is that property deserves protection to the extent that it promotes human dignity, that there exists in natural law a minimum standard for the treatment of property consistent with human dignity, and that redistribution of property can be justified when one person's dignity need is greater than that of another. ${ }^{115}$

As his starting point, Peñalver takes the Universal Declaration of Human Rights statement that human rights derive from "inherent human dignity," and explores two possible sources for these rights. Looking first to classical international law, Peñalver describes it as unable normatively to support such an expansive idea of human rights for three reasons. First, classical international law is concerned with the nation-state, to the point of overlooking the rights of individuals. Second, to the extent that classical international law does cognize individuals, it does so only with regard to nationals of another state. ${ }^{116}$ Third, the positivist preference of classical international law leaves it impotent in the face of conflicting or ambiguous sources. ${ }^{17}$

Peñalver then turns his analysis to natural law, and adopts as his primary source St. Thomas Aquinas's Social Theory of Property. ${ }^{118}$ Aquinas's theory was based on necessity, whereby a person in need did not violate the law by taking property from others in order to meet his minimum needs. ${ }^{119}$ Peñalver goes on to articulate his own three-tiered hierarchy of human dignity. He begins with a definition of dignity that is very similar to Margaret Radin's definition of personal property. Dignity is "the property a thing has when it has intrinsic value, when it is, literally, price-less." 120

Next, Peñalver describes three levels of human dignity that require protection through private property. The first level is "physical dignity," which

114. Peñalver, supra note 8 , at 155.

115. See id. at 200.

116. Id. at 110.

117. See id. at 111.

118. Id. at 190.

119. See id. at 192.

120. See id. at 196. 
includes basic survival needs such as food, clothing, and shelter. The second level is "developmental dignity," which includes the resources for the training and education needed to be able to form intelligent conclusions about the human telos. Examples of developmental dignity include family, which Peñalver says requires "[a] material sphere of property ... to protect the family from intrusion." 21 The third level is "expressive dignity" and involves the property necessary to act on moral and intellectual conclusions. Expressive dignity includes education of one's children, religious worship, political participation, work, friendship, liberality, and charity. ${ }^{122}$ Penalver asserts that the right to own property implies a positive right to both physical dignity property and developmental dignity property, but only a negative right to expressive dignity. ${ }^{123} \mathrm{He}$ also asserts that organizations can have expressive property rights to the extent that they come together for worship, political expression, or collective work. ${ }^{124}$ Finally, Peñalver says that these levels of property establish the minimum level of protection, which can be supplemented by international custom. Beyond this minimum, states retain an "undeniable right of sovereignty" to provide greater protections based on their own values and needs. ${ }^{125}$

\section{Reconciling Human Rights and Sovereignty}

As the world becomes smaller, and the welfare of people around the globe becomes dependent on how others define and apply property protections, the need for global property law becomes more compelling. Not only do we need global property law for its own sake, but the ultimate success of human rights, and the future of local governance, may depend on it. If we look again at the types of human rights in dispute in international law, we see that many of the socalled positive rights in the ICESCR appear as negative rights in U.S. constitutional law. Many scholars have even noted that there is significant overlap between the two. ${ }^{126}$ I hope to show that injecting a negative rights regime with human rights priorities is an achievable evolution of current law, and will go a long way toward securing social, economic, and cultural rights as well as a

121. Id. at 197.

122. See id. at 198.

123. Id. at 200.

124. Id.

125. Id. at 207.

126. See, e.g., Eide \& Rosas, supra note 16, at 16-17. 
permanent role for sovereign states in promoting public welfare through embedded governance. I take as my starting point the insights of Latham, Radin, and Peñalver described above. I will then demonstrate how these theories, taken together, might inform a global property framework, and will offer suggestions regarding five dynamics of such a system: a hierarchy of property rights, the distinction between negative and positive rights, judicial review of property disputes, compensation, and the role of sovereignty.

\section{A. Hierarchy of Property Rights}

As Latham reminds us, property's purpose is provision of material needs. ${ }^{127}$ While this is an essential reminder, and a useful starting point, it does not provide us with the theoretical ability to distinguish the relative importance of different types of property, and thus leaves us with the question of how to prioritize. Radin goes further by dividing property into two types, and demonstrating how courts and legislators have acted upon, if not articulated, an understanding of the relative importance of different types of property. ${ }^{128}$ Developing a strain that we see in Latham's writings, Radin identifies some property as speculative and disembedded, and thus deserving less protection than personal and imbedded property. ${ }^{129}$ However, Radin's theory lacks the tools for distinguishing between property with which people sustain themselves, and property through which people constitute themselves. Also, because Radin's theory is ultimately based on a person's subjective attachment to property, it fails to offer a way to distinguish between similar instances of personhood property that are economically disparate. It would seem, therefore, that a millionaire's mansion would be entitled to the same property protection as a hovel. Since one of the major problems with property today is the concentration of wealth, Radin's theory is inadequate for my purposes because it fails to support a redistributive mandate. ${ }^{130} \mathrm{Of}$ the three authors, Peñalver's hierarchy comes closest to what I would recommend. My main disagreement with his model is that he fails to create a category for property that is completely disembedded, and thus least deserving of protection. Peñalver's third category, expressive dignity, comes close, but lumps

127. Latham, supra note 80 , at 82 .

128. Radin, supra note 96 , at 957.

129. Id. at $959-60$.

130. Id. at $989,996$. 
religious worship, political participation, and work together with disembedded, speculative property, thereby confusing an essential distinction, diminishing the value of the former, and enhancing the value of the latter.

I would recommend a different three-tiered hierarchy. The highest level, which I would call "Needs Property," would include those rights which are beyond dispute in international law (e.g. food, shelter, health care, education, and employment). The middle level, which I would call "Rights Property," would include all other rights for which there is significant, but perhaps not universal, support, including various civil/political rights, and social/economic/ cultural rights (e.g.. privacy, expression, religion, marriage, family, child rearing, and association). Beyond the rights acknowledged in common, states would be free to include additional Rights Property in this class. The final level, which I would call Wealth Property, would include property that generates, and/or is generated by, wealth accumulation (e.g. investments, methods of production). The distinctions between these categories would be objective, and based on the use to which the property is put. For example, my home is Needs Property, whereas the apartment building that I own and rent out is Wealth Property. To the extent that two instances of Needs Property can be vastly different in value (the hovel versus the mansion), the legislature should articulate a reasonable limit to the value that will be protected.

\section{B. Negative Versus Positive Rights}

Both Latham and Peñalver argue that individuals have an affirmative right to Needs Property, and Peñalver adds that individuals have a negative right to the lower-level rights. ${ }^{131}$ Radin's theory employs only negative rights, and describes the relative weight of the negative rights that guard different types of property. ${ }^{132}$ I would follow Radin in expressing property rights only as negative, but valued against each other according to their place in the hierarchy. This is preferable to Peñalver's combination of positive and negative rights for several reasons. First, the concept of negative rights already has broad support, especially among capital-exporting countries (who would be most disadvantaged by, and therefore most resistant to, the rearrangement of priorities I suggest).

131. Latham, supra note 80 , at 83; Peñalver, supra note 8, at 199-200.

132. See generally Radin, supra note 96 . 
Second, it is easier to administer and adjudicate claims of negative rights. A mixed positive/negative regime could create situations of theft leading to class warfare on one extreme, and to hair-splitting distinctions to determine who is the neediest, on the other. Third, strong negative rights will have a redistributive effect, as will become clearer with the following discussions of standards of review and compensation.

\section{Judicial Review}

In order for a property hierarchy to have meaning in operation, it must be enforceable. As such, it requires a standard of judicial review for scrutinizing state action and balancing the relative rights of individuals. Of the three authors, only Radin offers a discussion of the appropriate level of judicial review. Though this approach has not been adopted by any jurisdiction, Radin suggests that government takings of personhood property should be subject to strict scrutiny. ${ }^{133}$ Consistent with this, I would assign increasingly strict levels of judicial review to the levels of the hierarchy.

Thus, for example, attempts by the state to take Needs Property (for instance, a home) will have to meet a compelling state interest, and must be necessary to accomplish that interest. Attempts to take Rights Property (such as a church) will have to meet an intermediate test under which there must be a substantial government interest, and the action must be narrowly tailored to accomplish that interest. Finally, takings of Wealth Property (a business) would remain subject to a very deferential rational basis test, under which there need only be a legitimate public purpose and the action need only be rationally related to the purpose.

This hierarchy of review could also inform a balancing test to be applied in disputes between private individuals. For example, a racially restrictive covenant would be struck down because the Needs Property interest (housing) outweighs the Rights Property interest (freedom of association). Protestors would be allowed to demonstrate at a mall because the Rights Property interest (speech) outweighs the Wealth Property interest (mall ownership). Finally, limits on a landlord's free alienation of his rental property, such as rent control, would be understood as Needs Property (housing) outweighing Wealth Property (rental income).

133. Id. at $1005-06$. 


\section{Compensation}

The final application of the new property framework would be to the question of compensation for takings. Radin's contribution to this question is in her suggestion that some property is so personal that its loss cannot be compensated, and thus the state should be prohibited from taking it. ${ }^{134}$ Also, as noted earlier, market-value compensation is often insufficient to compensate for all of the loss and suffering that occurs when people are displaced. ${ }^{135}$

I would create a compensation scale that corresponds to the property hierarchy. Such a scale would reinforce the relative values in the hierarchy by increasing the cost of taking Needs Property and Rights Property, and would, as a result, make them more stable. For Needs Property, compensation should be three times the market value, to help account for the "brutal" nature of being deprived of Needs Property, and to attempt to compensate for the immeasurable consequences of social, economic, and cultural dislocation. For Rights Property, compensation should be twice the market value, for similar reasons. And for Wealth Property, compensation should follow the standard American approach of paying market value. While this multiplier approach may sometimes fail to accurately compensate for a person's loss, fairness and ease of administration argue for adopting a simple and consistent standard.

\section{E. The Role of Sovereignty}

The final consideration for implementing a global property framework is the role to be played by sovereign states. As discussed earlier, due to the profound western bias and the power of global economic interests, Latham is suspicious of the state's ability to resist globalization and believes that in the era of globalization, "powerful boundaries-ideological or otherwise-[must] be placed around the action and capacities of states to interfere" with the making of market networks. ${ }^{136}$ At the same time, Latham is aware of the need to create local, embedded economies that conform to the needs of societies. ${ }^{137}$ Peñalver reminds us that because needs and norms vary greatly among states, the state has

134. Id. at 1005.

135. See generally Downing, supra note 82.

136. Latham, supra note 80 , at 80.

137. Id. at 78 . 
an essential role to play in giving meaning to a human-rights centered property regime, ${ }^{138}$ and recommends that states retain virtual plenary power to determine the specific content of their property regimes consistent with the minimum standards required by human rights. ${ }^{139}$

In order to reconcile these concerns, and fortify the important democratic role of sovereign states, I would conceive of the new property framework as operating in a federalist structure similar to that articulated by Daniel J. Elazar. ${ }^{140}$ Elazar suggests that states "remain the primary building blocks of the world order," while closely resembling the states in a federal arrangement: "with clearly defined territories, comprehensive governmental structures, and important functional responsibilities," but "parts of larger political arrangements and networks that both limit them and provide their people with new opportunities and essentially redefine their powers as jurisdictional rather than sovereign." 141 Thus, states would retain their relevance and role as protectors of local public welfare, while conforming to global mandates to protect and promote the full promise of human rights.

\section{Conclusion}

Globalization is transforming the world's concepts of human rights and sovereignty. Despite substantial agreement, there remain great divergence and increasing inequity in these areas. These disagreements are caused in large part by differences in conceptions of the relative rights and power of individuals and states, and the role that property plays in that power dynamic. Within this disagreement, however, are the seeds of consensus, calling for a solution. By focusing on this agreement, we can create a set of property values that promotes economic, social, and cultural rights and shores up the role of the state in the global era. The framework suggested by this note strikes a middle ground between liberalism and socialism. It would infuse the property protections of liberalism with the redistributive ethic of socialism by correlating protection with social value, and thus give property that promotes higher values greater stability and

\footnotetext{
138. Peñalver, supra note 8 , at 201-02.

139. Id. at 202.

140. Daniel J. Elazar, The State System + Globalization (Economic Plus Human Rights) $=$ Federal ism (State Federations Plus Regional Confederations), 40 S. Tex. L. Rev. 555 (1999).
}

141. Id. at 556. 
protection, while leaving the state free to regulate lower-value property for the public good. From the perspective of socialism, it stops the runaway sanctification of capitalist property rights by circumscribing the protection of speculative property. From the perspective of liberalism, it strengthens the fundamental rights and security of individuals as against the majority by increasing the expectation for protection of "rights-promoting" property. Finally, it depends on, and reinforces, the essential role of sovereign states in the era of globalization. Within this framework, the global community can agree on increased respect for, and commitment to, providing for human needs and protecting human rights. 
